\title{
OPEN Phytoremediation of electroplating wastewater by vetiver grass (Chrysopogon zizanoides L.)
}

Andhika Puspito Nugroho ${ }^{1}$, Erni Saurmalinda Butar Butar ${ }^{2 \varpi}$, Ekaputra Agung Priantoro², Lies Sriwuryandari ${ }^{2}$, Zulfa Berliana Pratiwi ${ }^{1}$ \& Tarzan Sembiring ${ }^{2}$

The electroplating industry generates wastewater containing a variety of heavy metals which potentially contaminate water ecosystems. The available and well-known electroplating wastewater treatments are considered as an expensive and less effective method, therefore phytoremediation was used as an alternative friendly solution. This study aims to evaluate the uptake and elimination rate of heavy metals by vetiver (Chrysopogon zizanoides L.) on metal-polluted water. Vetiver was planted in artificial electroplating wastewater containing different levels (low, medium, high) of chromium ( $\mathrm{Cr}$ ) and nickel (Ni). Water, roots, and shoots were collected periodically to determine $\mathrm{Cr}$ and $\mathrm{Ni}$ contents using Atomic Absorption Spectrometry (AAS). Metal accumulation and elimination rate, Bioconcentration Factor (BCF), Biological Absorption Coefficient (BAC), and Translocation Factor (TF) were calculated to evaluate plant's effectiveness in metal remediation processes. The results showed that vetiver (C. zizanoides $L$.) was able to remove $61.10 \% \mathrm{Cr}$ and $95.65 \% \mathrm{Ni}$ on metal-contaminated water. The highest uptake rates for $\mathrm{Cr}$ and $\mathrm{Ni}$ are $127.21 \mathrm{mg} / \mathrm{kg} / \mathrm{day}$ and $15.60 \mathrm{mg} / \mathrm{kg} /$ day respectively, while the elimination rates for $\mathrm{Cr}$ and $\mathrm{Ni}$ tend to slow $1.09 \mathrm{mg} / \mathrm{kg} / \mathrm{day}$ and $12.24 \mathrm{mg} / \mathrm{kg} / \mathrm{day}$ respectively. Vetiver BCF, BAC, and TF values on $\mathrm{Cr}$ and $\mathrm{Ni}$ contaminated water were greater than 1 , which indicates that vetiver work through phytoextraction and phytostabilization to treat metals. The findings showed that vetiver has promise as a phytoremediation agent thus providing implication for electroplating wastewater treatment.

Wastewater from electroplating industrial activities became major concern due to high variety and concentration of heavy metals ${ }^{1,2}$. This attracted great attention in terms of environmental impact and removal technique ${ }^{3}$. Once heavy metal contaminate the aquatic ecosystem, the metal's toxicity, carcinogenicity, mutagenicity may adverse the aquatic life ${ }^{4}$. Metal is persisted to the environment ${ }^{4,5}$, and potentially to be biomagnified through the food chain ${ }^{6-9}$.

The discharge of metal ions such as chromium (Cr) and nickel (Ni) into surface water may impact on living organism ${ }^{10}$. Chromium has several oxidation states $(-2$ to +6$), \mathrm{Cr}$ (VI) and $\mathrm{Cr}$ (III) is the most common form in the environment, $\mathrm{Cr}$ (III) is less toxic than $\mathrm{Cr}(\mathrm{VI})^{11-14}$. While $\mathrm{Ni}$ is one of the plant micronutrients, it helps the formation of enzymes such as urease ${ }^{15}$. However, high $\mathrm{Cr}$ and $\mathrm{Ni}$ levels in the environment may induce plant toxicity such as chlorosis, necrosis, damage on root cells, wilting, nutritional deficiency, disruption of enzymatic activity and induce reactive oxygen species (ROS $)^{16-18}$. Recent electroplating wastewater treatment is considered as an expensive and less effective method, it could produce secondary pollutants ${ }^{19}$. Therefore it is imperative to evaluate phytoremediation as an easy, inexpensive, and environmentally friendly solution in order to remove heavy metals ${ }^{20,21}$.

Phytoremediation is a green technology to remediate environmental pollutants by employing plants ${ }^{22-25}$. Plantsable to accumulate pollutants including heavy metals through phytoextraction, phytostabilization, rhizodegradation, phytotransformation, phytodegradation, and phytovolatilization processes ${ }^{26-29}$. The ability of plants to accumulate and eliminate high content of heavy metals were needed in phytoremediation processes ${ }^{16,30}$. In order to respond to heavy metal stress in the environment, plants produce chelators and organic acids to bind with toxic metal ions ${ }^{31-34}$. The complex between metal and chelator were sequestrated by cell, so the metal ions were inactivated through compartmentalization in cellular parts of plant ${ }^{15,35}$.

${ }^{1}$ Faculty of Biology, Universitas Gadjah Mada, Yogyakarta, Indonesia. ${ }^{2}$ Waste Treatment and Environmental Management Working Group, Research Unit for Clean Technology - Indonesian Institute of Sciences, Bandung, Indonesia. ${ }^{\circledR}$ email: butarbutarernie@gmail.com 


\begin{tabular}{|c|c|c|c|c|}
\hline \multirow[b]{2}{*}{ Treatments } & \multicolumn{2}{|c|}{ Uptake (mg/L) } & \multicolumn{2}{|c|}{$\begin{array}{l}\text { Elimination } \\
(\mathrm{mg} / \mathrm{L})\end{array}$} \\
\hline & Do & D28 & Do & D28 \\
\hline \multicolumn{5}{|l|}{ Control } \\
\hline $\mathrm{Cr}$ & $0.0000^{\mathrm{a}}$ & $0.0000^{\mathrm{a}}$ & $0.0000^{\mathrm{a}}$ & $0.0000^{\mathrm{a}}$ \\
\hline $\mathrm{Ni}$ & $0.0000^{\mathrm{a}}$ & $0.0000^{\mathrm{a}}$ & $0.0000^{\mathrm{a}}$ & $0.0000^{\mathrm{a}}$ \\
\hline \multicolumn{5}{|l|}{$\mathrm{Cr}$} \\
\hline A & $50.7741^{\mathrm{b}}$ & $19.7494^{\mathrm{b}}$ & $0.0000^{\mathrm{a}}$ & $0.2292^{\mathrm{b}}$ \\
\hline $\mathrm{B}$ & $155.2206^{c}$ & $86.9938^{c}$ & $0.0000^{\mathrm{a}}$ & $0.5737^{\circ}$ \\
\hline $\mathrm{C}$ & $346.9057^{\mathrm{d}}$ & $190.3750^{\mathrm{d}}$ & $0.0000^{\mathrm{a}}$ & $0.9380^{\mathrm{d}}$ \\
\hline \multicolumn{5}{|l|}{$\mathrm{Ni}$} \\
\hline A & $24.7387^{\mathrm{b}}$ & $1.0767^{\mathrm{a}}$ & $0.0000^{\mathrm{a}}$ & $0.2113^{\mathrm{b}}$ \\
\hline $\mathrm{B}$ & $76.3505^{\mathrm{c}}$ & $12.6903^{\mathrm{b}}$ & \begin{tabular}{|l}
$0.0000^{\mathrm{a}}$ \\
\end{tabular} & $0.5473^{\circ}$ \\
\hline $\mathrm{C}$ & $156.8409^{d}$ & $34.0900^{c}$ & $0.0000^{\mathrm{a}}$ & $0.6923^{\circ}$ \\
\hline
\end{tabular}

Table 1. Cr and Ni levels on vetiver (C. zizanoides L.) growth media. Information: A (Low concentration); B (Medium concentration); C (High concentration). Identical letter indicated statistically no significant different $(\mathrm{p}>0.05)$.

Vetiver (C. zizanoides L.) has exhibited the potential for polluted water treatment and phytoremediation ${ }^{7}$. As a perennial grass, it was reported that vetiver was high tolerance and effective to reduce heavy metals in wastewater ${ }^{7,22,35,36}$. Vetiver has a wide range of environmental factor tolerances. Although vetiver is terrestrial plant, it grows rapidly and is able to adapt and grow in water, acid environment and temperature stress ${ }^{22,26,37,38}$. Vetiver has erected and stiff shoots, it has massive, deep, and fast-growing root system ${ }^{39}$. These root systems provide an enormous surface area for vetiver to absorb large amounts of pollutant rather than the other species ${ }^{6,39}$. The morphological character of vetiver indicated that plants were suitable as potential phytoremediation agents. Therefore, this study was aimed to understand the metals uptake and elimination rates by vetiver in order to evaluate vetiver as a potential phytoremediation agent.

\section{Results and discussion}

Phytoremediation of $\mathrm{Cr}$ and $\mathrm{Ni}$ is shown that heavy metal content in plant growth media were reduced during 28 days remediation by vetiver grass (C. zizanoides L.). The results showed heavy metal reduction were $61.10 \%$ and $95.65 \%$ in $\mathrm{Cr}-\mathrm{A}$ treatment and $\mathrm{Ni}$-A treatment respectively (Table 1 ). The result was relatively greater than the previous report, where $\mathrm{Cr}$ and $\mathrm{Ni}$ reduction was about $21 \%$ and $38 \%$ respectively on $\mathrm{Cr}$ and $\mathrm{Ni}$ elimination from acid mines ${ }^{40}$. However, during 28 days of metal exposure, vetiver plants were affected by Cr toxicity. It was observed in the first 20 day that the grass loss on water content and turgor pressure, wilting, chlorosis, and root cells disruption. Meanwhile, in Ni treatment, the toxicity symptoms that arose in plants are chlorosis, wilting, and necrosis.

Despite the series of toxicity symptoms, the vetiver in this experiment was found to be well adapted, indicated with the growth of roots and new individuals in the $\mathrm{Cr}$ and Ni treatment. The ability of plants to absorb large amounts of metals and reduce their toxicity is a key factor for the remediation process. This proves that vetiver has a high potential as phytoremediation agent.

During elimination condition $0.60-0.80 \% \mathrm{Cr}$ and $0.60-0.89 \% \mathrm{Ni}$ were released back to the plant growth medium (Table 1). The mechanism is used by plants to reduce heavy metals toxicity by controlling the level of heavy metals accumulation in plant cells. The efflux system consisting of P1B-ATPases and CDF transporter families on roots plasma membrane is involved on this mechanism ${ }^{41-44}$.

The concentration of chromium and nickel content in shoots of vetiver (C. zizanoides L.) were increased during 28 days remediation (uptake condition) (Fig. 1a). The metals uptake and translocation in vetiver (C. zizanoides $\mathrm{L}$.) occurs gradually over the length of time metal exposure. The highest $\mathrm{Cr}$ and $\mathrm{Ni}$ accumulation in shoots were $1817.0894 \mathrm{mg} / \mathrm{kg}$, DW and $295.9948 \mathrm{mg} / \mathrm{kg}$, DW respectively. The metals uptake can be affected by metal levels on plant growth medium. High number of biomass was needed to accumulate high metal concentration, therefore NPK and fertilizer were added to support vetiver growth ${ }^{45}$. Chromium and nickel were translocated from vetiver roots to shoots through xilem ${ }^{46,47}$. The translocation process both metals tend to be slow $^{48,49}$ because of $\mathrm{Cr}$ tend to be retained on roots vacuole and cell wall ${ }^{11,50-52}$, while more than $50 \%$ absorbed nickel were retained in roots cylinder vascular ${ }^{49,53}$.

Metals content in vetiver shoots during elimination condition tend to decrease after reaching the peak of metal accumulation (Fig. 1b). Nevertheless, it was found that metal accumulation in Cr-C treatment still increased until the end of the elimination condition. This indicates that the $\mathrm{Cr}$ concentration in $\mathrm{Cr}-\mathrm{C}$ treatment is too high or not proportional to the slow development of plant biomass. Hence, a longer observation time is needed to understand the elimination of high Cr concentrations in vetiver. Vetiver transfer into non-metal contaminated medium during elimination conditions may support the plant growth. As the plant grows, new biomass will be formed and excess metal will be translocated into younger tissues, therefore the shoots metal content was reduced through the time. Study revealed that chromium and nickel were translocated into older tissue in order to protect young tissues ${ }^{49,54}$. 
(a)


(b)
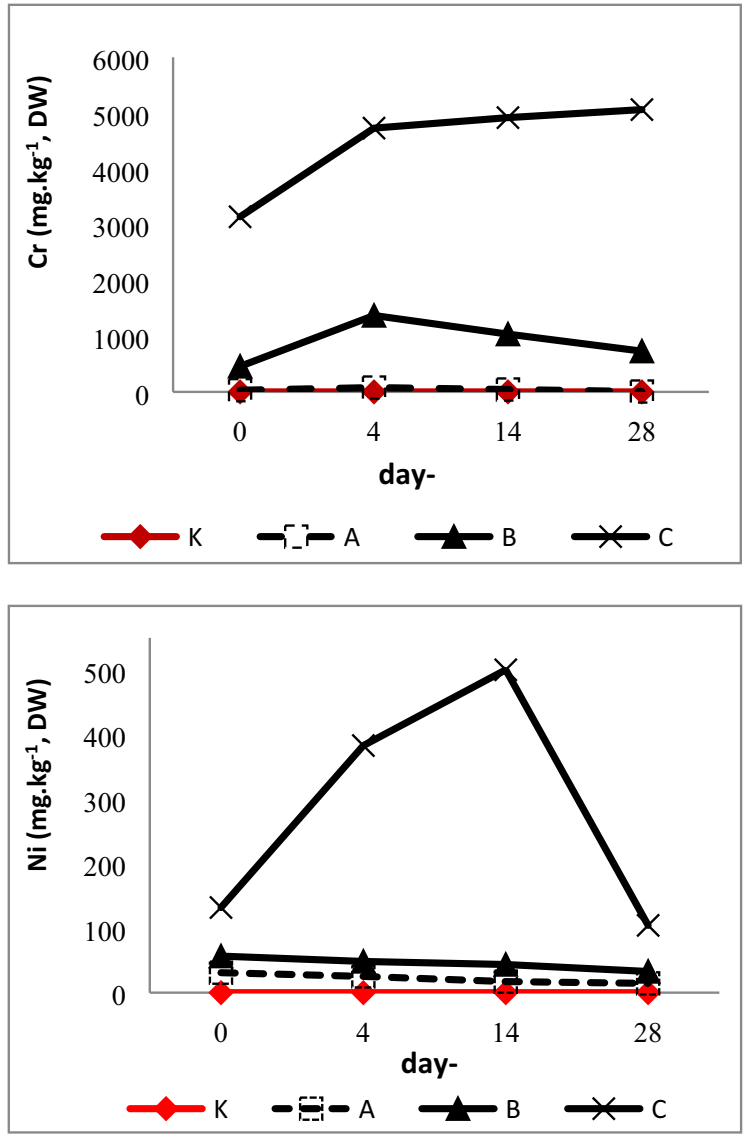

Figure 1. Cr and Ni content in shoots of vetiver (C. zizanoides L.): (a) uptake condition, (b) elimination condition.

\begin{tabular}{|l|c|r|r|r|r|r|}
\hline \multirow{2}{*}{ Samples } & \multicolumn{4}{|l|}{$\begin{array}{l}\text { Rate of uptake (mg/ } \\
\text { kg/day) }\end{array}$} & \multicolumn{1}{|l|}{} & \multicolumn{3}{|c|}{ Rate of elimination (mg/kg/day) } \\
\cline { 2 - 8 } & $\mathbf{1 4}$ & $\mathbf{2 8}$ & $\mathbf{4}$ & $\mathbf{1 4}$ & $\mathbf{2 8}$ \\
\hline $\mathrm{Cr}-\mathrm{A}$ & 1.81 & 0.79 & 1.32 & -10.17 & -0.41 & 1.09 \\
\hline $\mathrm{Cr}-\mathrm{B}$ & 5.61 & 8.33 & 20.38 & -199.86 & -33.23 & -5.62 \\
\hline $\mathrm{Cr}-\mathrm{C}$ & 77.06 & 127.21 & 64.90 & -728.05 & -221.45 & -115.87 \\
\hline $\mathrm{Ni}-\mathrm{A}$ & 0.97 & 0.60 & 0.55 & -2.43 & -0.12 & 0.04 \\
\hline $\mathrm{Ni}-\mathrm{B}$ & 3.64 & 5.17 & 3.48 & 12.24 & 3.84 & 2.30 \\
\hline $\mathrm{Ni}-\mathrm{C}$ & 15.60 & 11.63 & 10.57 & -21.76 & -14.61 & 6.85 \\
\hline
\end{tabular}

Table 2. Rate of heavy metals uptake and elimination in vetiver (C. zizanoides L.). Information: A (Low concentration); B (Medium concentration); C (High concentration).

Rate of metals uptake in vetiver (C. zizanoides L.) strongly related with metal concentration in plant growth media. Heavy metals stress induced chelator production which is used by plants to form metals-chelator complex in order to reduce metal toxicity ${ }^{15}$. Metal accumulation in plants was accelerated with the formation of this complex, therefore the rate of metals uptake was increased as the increase of metal content in growth media (Table 2). It was reported that vetiver accumulates chromium better than nickel ${ }^{55}$, as seen on the result, the rate of chromium uptake is higher than nickel.

The rate of metals elimination after plants were moved into non-metal contaminated water is extremely slow. Toxic metals can be eliminated by plant through sequestration metal-chelator complex into inactive form, this mechanism is aided by tonoplast antiporter such as cation diffusion facilitator (CDF), cation exchanger (CAX), and magnesium exchangers ${ }^{15}$. Although vetiver has a slow metal elimination rate, it is known to be adaptive in heavy metal stress. Plants with high ability to sequestrate metals were known as good potential phytoremediation $^{16,22}$.

Vetiver (C. zizanoides L.) potential as a phytoremediation agent can be determined by some index including bioconcentration factor (BCF), biological absorption coefficient (BAC), and translocation factor (TF). Plants with 


\begin{tabular}{|c|c|c|c|c|c|c|}
\hline Samples & Root (mg/kg, DW) & Shoot $(\mathrm{mg} / \mathrm{kg}, \mathrm{DW})$ & Water $(\mathbf{m g} / \mathbf{k g})$ & BCF & BAC & TF \\
\hline \multicolumn{7}{|c|}{ Uptake condition } \\
\hline $\mathrm{Cr}-\mathrm{K}$ & $33.91^{\mathrm{a}} \pm 1.47$ & $0.00^{\mathrm{a}} \pm 0.00$ & 0.13 & & & \\
\hline Cr-A & $1776.62^{\mathrm{b}} \pm 9.87$ & $36.97^{\mathrm{b}} \pm 0.19$ & 19.75 & 89.96 & 1.87 & 0.02 \\
\hline $\mathrm{Cr}-\mathrm{B}$ & $2205.82^{\mathrm{c}} \pm 7.33$ & $570.59^{c} \pm 1.33$ & 86.99 & 25.36 & 6.56 & 0.26 \\
\hline $\mathrm{Cr}-\mathrm{C}$ & $3173.70^{\mathrm{d}} \pm 54.05$ & $1817.09^{\mathrm{d}} \pm 4.06$ & 190.38 & 16.67 & 9.54 & 0.57 \\
\hline \multicolumn{7}{|c|}{ Elimination condition } \\
\hline $\mathrm{Cr}-\mathrm{K}$ & $43.61^{\mathrm{a}} \pm 1.08$ & $0.00^{\mathrm{a}} \pm 0.00$ & 0.00 & & & \\
\hline $\mathrm{Cr}-\mathrm{A}$ & $668.84^{\mathrm{b}} \pm 7.65$ & $6.51^{\mathrm{b}} \pm 0.94$ & 0.23 & 2918.16 & 28.41 & 0.01 \\
\hline $\mathrm{Cr}-\mathrm{B}$ & $1734.06^{\mathrm{c}} \pm 0.63$ & $730.19^{c} \pm 3.95$ & 0.57 & 3022.60 & 1268.80 & 0.42 \\
\hline $\mathrm{Cr}-\mathrm{C}$ & $2468.07^{\mathrm{d}} \pm 24.47$ & $5061.57^{\mathrm{d}} \pm 13.82$ & 0.94 & 2631.21 & 5396.13 & 2.05 \\
\hline
\end{tabular}

Table 3. Cr content in root, shoot, and plant growth media after 28 days metal exposure and 28 days moved into freshwater. Information: K (Control); A (Low concentration); B (Medium concentration); C (High concentration). Identical letter indicated statistically no significant different $(p>0.05)$.

\begin{tabular}{|c|c|c|c|c|c|c|}
\hline Samples & Root $(\mathrm{mg} / \mathrm{kg}, \mathrm{DW})$ & Shoot $(\mathrm{mg} / \mathrm{kg}, \mathrm{DW})$ & Water (mg/kg) & BCF & BAC & TF \\
\hline \multicolumn{7}{|c|}{ Uptake condition } \\
\hline $\mathrm{Ni}-\mathrm{K}$ & $22.30^{\mathrm{a}} \pm 0.25$ & $0.00^{\mathrm{a}} \pm 0.00$ & 0.00 & & & \\
\hline $\mathrm{Ni}-\mathrm{A}$ & $1279.20^{\mathrm{b}} \pm 5.20$ & $15.49^{\mathrm{b}} \pm 1.45$ & 1.08 & 1188.08 & 14.39 & 0.01 \\
\hline $\mathrm{Ni}-\mathrm{B}$ & $1563.01^{c} \pm 10.18$ & $97.35^{\mathrm{c}} \pm 0.41$ & 12.69 & 123.166 & 7.67 & 0.06 \\
\hline $\mathrm{Ni}-\mathrm{C}$ & $16,533.21^{\mathrm{d}} \pm 9.48$ & $295.99^{\mathrm{d}} \pm 0.32$ & 34.09 & 48.4954 & 8.68 & 0.18 \\
\hline \multicolumn{7}{|c|}{ Elimination condition } \\
\hline $\mathrm{Ni}-\mathrm{K}$ & $8.60^{\mathrm{a}} \pm 0.37$ & $0.00^{\mathrm{a}} \pm 0.00$ & 0.00 & & & \\
\hline $\mathrm{Ni}-\mathrm{A}$ & $625.03^{\mathrm{b}} \pm 3.57$ & $14.28^{\mathrm{b}} \pm 0.66$ & 0.21 & 2958.73 & 68.05 & 0.02 \\
\hline $\mathrm{Ni}-\mathrm{B}$ & $576.00^{c} \pm 2.65$ & $32.82^{\mathrm{c}} \pm 0.66$ & 0.55 & 1052.53 & 59.97 & 0.06 \\
\hline $\mathrm{Ni}-\mathrm{C}$ & $998.60^{\mathrm{d}} \pm 8.75$ & $104.29^{\mathrm{d}} \pm 0.35$ & 0.69 & 1442.43 & 150.64 & 0.10 \\
\hline
\end{tabular}

Table 4. Ni content in root, shoot, and plant growth media after 28 days metal exposure and 28 days moved into freshwater. Information: K (Control); A (Low concentration); B (Medium concentration); C (High concentration). Identical letter indicated statistically no significant different $(p>0.05)$.

$\mathrm{BAC} \geq 1, \mathrm{BCF} \geq 1, \mathrm{TF} \geq 1$ classified as metal hyperaccumulator with strong phytoextraction capacity, while plants with $\mathrm{BAC} \geq 1, \mathrm{BCF} \geq 1, \mathrm{TF} \leq 1$ classified as metal hyperaccumulator through phytostabilization mechanism ${ }^{56-58}$. Plants were classified as metal hyperaccumulators when they were able to accumulate $>1000 \mathrm{mg} / \mathrm{kg}$, DW metals in their tissues ${ }^{57,59,60}$.

Vetiver (C. zizanoides L) able to accumulate $\mathrm{Cr}>1000 \mathrm{mg} / \mathrm{kg}$, DW and possess great BAC, BCF, TF values (Table 3). It is suggested that vetiver possess strong phytoextraction and phytostabilization capacity for chromium. On the other hand vetiver was not able to accumulate nickel $>1000 \mathrm{mg} / \mathrm{kg}, \mathrm{DW}$, it means vetiver could not be classified as a nickel hyper-accumulator. However, it has high BAC and BCF values (Table 4), so it could be classified as a good potential phytoremediation for nickel with phytostabilization capacity. Together, these results indicate that vetiver (C. zizanoides L.) tissues possess a high capacity for heavy metals accumulation, it may grow normally in a metal-polluted environment, and is thus becoming a promising metal pollution tolerant plant species.

Heavy metals became an inert form inside the plant cells ${ }^{15}$, to become the part of plant biomass. Disposal strategies for metal rich senescent leaves are also needed in order to prevent secondary metals contamination issues $^{53}$. Pyrolysis, gasification, incineration, and volume reduction processes such as composting and compacting are some of the methods that are usually used to manage metal rich plant biomass ${ }^{53}$.

\section{Conclusions}

Based on the results we concluded that $C$. zizanoides $L$. potentially used as a phytoremediation agent for electroplating wastewater treatment. It significantly reduced $\mathrm{Cr}$ and $\mathrm{Ni}$ levels on electroplating wastewater. Metal accumulation and elimination rate by $C$. zizanoides $L$ strongly indicated the capability $C$. zizanoides $L$. to uptake and detoxify metals on its biomass. Furthermore, great BAC, BCF, and TF values suggest that $C$. zizanoides $L$. are capable of processing process phytoextraction and phytostabilization during remediation processes.

\section{Method and materials}

Preliminary. Tools experiments were soaked with $\mathrm{HNO}_{3} 0.1 \mathrm{M}$ overnight and rinsed with distilled water. Vetiver which adapted to water-growth media was selected. To obtain a solitary plant, vetiver were separated from the clump and moved to another container to be acclimatized. Electroplating wastewater was made artifi- 


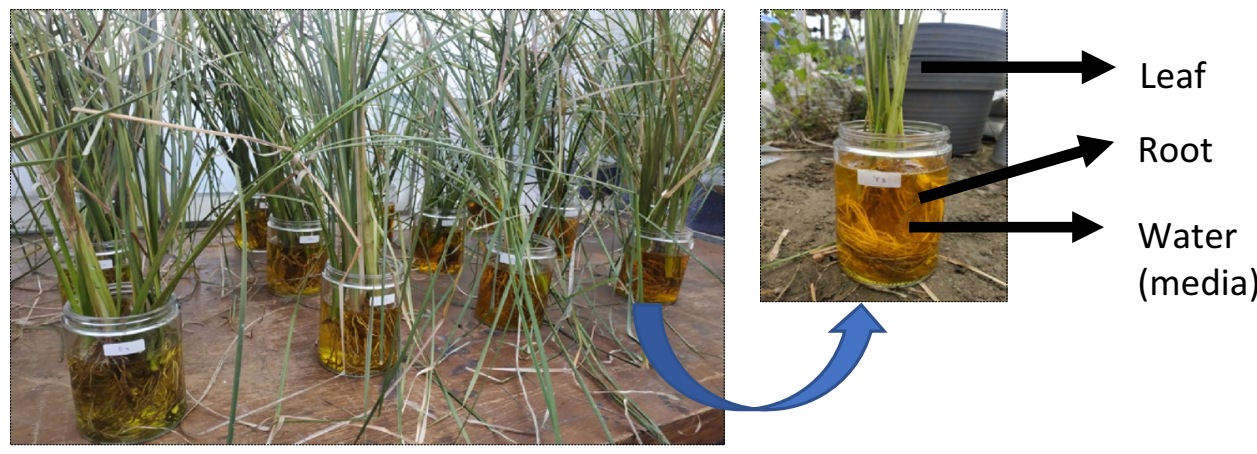

Figure 2. Sampling vetiver site.

cially using $\mathrm{K}_{2} \mathrm{Cr}_{2} \mathrm{O}_{7}$ and $\mathrm{NiSO}_{4} \cdot 6 \mathrm{H}_{2} \mathrm{O}$. Chromium concentrate solution was made with diluting $5.66 \mathrm{~g} \mathrm{~K}_{2} \mathrm{Cr}_{2} \mathrm{O}_{7}$ in a $1000 \mathrm{~mL}$ reaction flask, while nickel standard solution was made by diluting $4.48 \mathrm{~g} \mathrm{NiSO}_{4} \cdot 6 \mathrm{H}_{2} \mathrm{O}$ in a $1000 \mathrm{~mL}$ aquabidest. Different levels concentration of chromium $(\mathrm{Cr})$ and nickel $(\mathrm{Ni})$ as artificial wastewater were made by dilution of concentrate solution.

Plant materials. Vetiver used in the experiment is nursery and cultivated in Green house, a collection of Laboratory for Waste and Wastewater management- Research Unit for Clean Technology-Indonesian Institute of Sciences. After the experiment all vetiver materials including samples would be ignite and the ash collected in a special container before deposit in hazardous waste deposit bureau belong to national government. The use of the plant fulfills the law according to the letter of permission no: B-390/IV/DI.01.03/5/2021 from The Secretariat of Scientific Authority for Biodiversity-Indonesian Institute of Sciences.

Heavy metal exposure. Artificial wastewater was used as plant growth media. C. zizanoides L. were moved to metal-contaminated growth media indicated that the day- 0 of metal exposure. Plants were exposed to metal for 28 days indicating uptake condition, then plants were moved into non-metal contaminated growth media for 28 days indicating the elimination condition. To minimize the loss of water due to evapotranspiration, distilled water was added into plant growth media until reaches the initial volume of water growth media. Fertilizer (6.20 g NPK and $2.06 \mathrm{~g}$ urea diluted in $100 \mathrm{~mL}$ water) and compost leachates $(5 \mathrm{~g})$ were added on the day- 0 both in uptake and elimination conditions to meet plants nutrition.

Sampling. We collected samples consisting of water (media), leaf, and root samples. Sampling site was shown on Fig. 2. Water samples were collected at the day- 0 and day- 28 both in uptake and elimination conditions for metal content and Chemical Oxygen Demand (COD) determination. Leaf samples were collected atday- $0,4,14$, 28 of both in uptake and elimination conditions, for metal content determination. Root samples were also taken at day- 0 and day- 28 both in uptake and elimination conditions for the determination of metal content. Water acidity $(\mathrm{pH})$, water temperature, humidity, and air temperature were collected as additional supporting data.

Samples measurement. The water samples were filtered using Whatman 42 (pore size $2.5 \mu \mathrm{m}$ ) then $50 \mathrm{~mL}$ of water were digested using $5 \mathrm{~mL} \mathrm{HNO}_{3}$ in $250 \mathrm{~mL}$ Erlenmeyer which was covered by glass funnel. Samples were heated slowly until reaching a clear color and the remaining volume is about $15-20 \mathrm{ml}$. Waterdigested samples were diluted and homogenized with $50 \mathrm{~mL}$ distilled water before measurement. The plant samples were dried in an oven at $70{ }^{\circ} \mathrm{C}$ to a constant weight. The dried plant tissues were subsequently weighed and ground into powder. Two (2) $\mathrm{mL}$ of $\mathrm{HNO}_{3} 65 \%$ were added to $0.2 \mathrm{~g}$ of plant samples in a $100 \mathrm{ml}$ Erlenmeyer and stirred. Then $1.6 \mathrm{~mL}$ of $\mathrm{H}_{2} \mathrm{O}_{2} 33 \%$ were carefully added and slightly stirred after the addition, followed by heating the sample on a hot plate, then a strong effervescence would be produced. At about 7-8 min the brown fumes produced were less dense and it allowed for cooling. A slightly yellow solution was obtained, filtered and washed with $5 \mathrm{~mL}$ of $(1: 1) \mathrm{HCl}$ (density $1.18 \mathrm{~g} / \mathrm{mL}$ ) and diluted with $25 \mathrm{~mL}$ of distilled water. The heavy metals contents of all samples were measured using Atomic Absorption Spectrometry (Agilent Technology). Chemical Oxygen Demand (COD) was determined using Spectrophotometer UV-Vis (Agilent Technology). $1.5 \mathrm{~mL}$ of water sample for COD measurement were added into reagent which contain the mixture of $750 \mathrm{~mL} \mathrm{H}_{2} \mathrm{SO}_{4}$, $25 \mathrm{~mL}$ orthophosphate, $15 \mathrm{~g} \mathrm{Cr}_{2} \mathrm{O}_{7}, 10 \mathrm{gr} \mathrm{Ag}_{2} \mathrm{SO}_{4}$, then reflux for $2 \mathrm{~h}$ at the temperature $150{ }^{\circ} \mathrm{C}$.

Analysis. The results were tabulated in Microsoft Excel 2016. Statistical analysis independent t-test $(\mathrm{p}<0.05)$ were conducted using software IBM SPSS Statistics v.16. Bioconcentration Factor (BCF) as metal concentration ratio of plant roots to the water, Biological Absorption Coefficient (BAC) as ratio heavy metal content in plant and the water, and Translocation Factor (TF) as ratio of metal concentration in the shoot to the root were calculated using the following formula ${ }^{61}$ : 


$$
\mathrm{BCF}=\frac{\text { Metal level }_{\text {root }}}{\text { Metal level }_{\text {water }}} \quad \mathrm{BAC}=\frac{\text { Metal level }_{\text {} h o o t}}{\text { Metal level }_{\text {water }}} \quad \mathrm{TF}=\frac{\text { Metal level }_{\text {shoot }}}{\text { Metal level }_{\text {root }}}
$$

The rate of metal uptake and elimination by plats were calculated as follows ${ }^{62}$ :

$$
\text { Rate of metal uptake }=\frac{\text { Metal level }_{\text {exposed }}-\text { Metal level }}{\text { control }}
$$

Rate of metal elimination $=\frac{\text { Metal level }_{\text {end of metal exposure }}-\text { Metal level }_{\text {end } \text { of metal elimination }}}{\text { Day }(\mathrm{s}) \text { of metal elimination }(\text { day })}$

Received: 29 September 2020; Accepted: 14 June 2021

Published online: 14 July 2021

\section{References}

1. Reis, M. T. A. \& Ismael, M. R. C. Electroplating wastes. Phys. Sci. Rev. https://doi.org/10.1515/psr-2018-0024 (2018).

2. Algarra, M., Jimenez, M. V., Rodriguez-Castellon, E., Jimenez-Lopez, A. \& Jimenez-Jimenez, J. Heavy metals removal from electroplating wastewater by aminopropyl-Si MCM-41. Chemosphere 59, 779-786 (2005).

3. Yao, X. et al. Highly efficient removal of hexavalent chromium from electroplating wastewater using aminated wheat straw. RSC Adv. 6, 8797-8805 (2016).

4. Hoque, E. \& Fritscher, J. Multimetal bioremediation and biomining by a combination of new aquatic strains of Mucor hiemalis. Sci. Rep. 9, 1-16 (2019).

5. Forstner, U. Metal Pollution in the Aquatic Environment (Springer-Verlag, 1979).

6. Islam, S., Ahmed, K., Raknuzzaman, M. \& Kundu, G. K. Heavy metals in the industrial sludge and their ecological risk: A case study for a developing country. J. Geochem. Explor. https://doi.org/10.1016/j.gexplo.2016.09.006 (2016).

7. Kafil, M., Nasab, S. B., Moazed, H. \& Bhatnagar, A. Phytoremediation potential of vetiver grass irrigated with wastewater for treatment of metal contaminated soil. Int. J. Phytoremediat. https://doi.org/10.1080/15226514.2018.1474443 (2019).

8. Ackova, D. G. Heavy metals and their general toxicity on plants. Plant Sci. Today 5, 14-18 (2018).

9. Algül, F. \& Beyhan, M. Concentrations and sources of heavy metals in shallow sediments in Lake Bafa, Turkey. Sci. Rep. 10, 1-12 (2020).

10. Goher, M. E., Hassan, A. M., Abdel-moniem, I. A., Fahmy, A. H. \& El-sayed, S. M. Evaluation of surface water quality and heavy metal indices of Ismailia Canal, Nile River, Egypt. Egypt. J. Aquat. Res. 40, 225-233 (2014).

11. Shahid, M. et al. Chromium speciation, bioavailability, uptake, toxicity and detoxification in soil-plant system: A review. Chemosphere 178, 513-533 (2017).

12. Bandara, P. C., Peña-Bahamonde, J. \& Rodrigues, D. F. Redox mechanisms of conversion of Cr (VI) to Cr (III) by graphene oxidepolymer composite. Sci. Rep. 10, 9237 (2020).

13. Tumolo, M. et al. Chromium pollution in European Water, sources, health risk, and remediation strategies: An overview. Int. J. Environ. Res. Public Health 17, 5438 (2020).

14. Lotfi, S., Chakit, M. \& Belghyti, D. Groundwater quality and pollution index for heavy metals in Saïs Plain, Morocco. J. Health Pollut. 10, 200603 (2020).

15. He, S., He, Z., Yang, X. \& Baligar, V. C. Mechanisms of nickel uptake and hyperaccumulation by plants and implications for soil remediation. Adv. Agron. https://doi.org/10.1016/B978-0-12-394278-4.00003-9 (2012).

16. Laghlimi, M., Baghdad, B., Hadi, H. E. \& Bouabdli, A. Phytoremediation mechanisms of heavy metal contaminated soils: A review. Open J. Ecol. 5, 375-388 (2015).

17. Hassan, M. U. et al. Nickel toxicity in plants: Reasons, toxic effects, tolerance mechanisms, and remediation possibilities - a review. Environ. Sci. Pollut. Res. 26, 12673-12688 (2019).

18. Nie, J. et al. A comparative study on the uptake and toxicity of nickel added in the form of different salts to maize seedlings. Environ. Res. Public Health 12, 15075-15087 (2015).

19. Rahman, L., Sarkar, S. M. \& Yusoff, M. M. Efficient removal of heavy metals from electroplating wastewater using polymer ligands. Front. Environ. Sci. Eng. 10, 352-361 (2015).

20. Liu, Z. et al. Effects of phytoremediation on industrial wastewater. Earth Environ. Sci. https://doi.org/10.1088/1755-1315/371/3/ 032011 (2019).

21. Suelee, A. L., Hasan, S. N. M. S., Kusin, F. M., Yusuff, F. M. \& Ibrahim, Z. Z. Phytoremediation potential of vetiver grass (Vetiveria zizanioides) for treatment of metal-contaminated water. Water Air Soil Pollut. 228, 1-15 (2017).

22. Sarma, H. Metal hyperaccumulation in plants: A review focusing on phytoremediation technology. J. Environ. Sci. Technol. 4, $118-138$ (2011).

23. Schwitzguébel, J. \& Comino, E. Is phytoremediation a sustainable and reliable approach to clean-up contaminated water and soil in Alpine areas ?. Environ. Sci. Pollut. Res. 18, 842-856 (2011).

24. Shmaefsky, B. R. Principles of phytoremediation. In Phytoremediation. Concepts and Strategies in Plant Sciences (ed. Shmaefsky, B. R.) (Springer, 2020).

25. Buendía-gonzález, L., Orozco-villafuerte, J., Cruz-sosa, F., Barrera-díaz, C. E. \& Vernon-carter, E. J. Prosopis laevigata a potential chromium (VI) and cadmium (II) hyperaccumulator desert plant. Bioresour. Technol. 101, 5862-5867 (2010).

26. Prabakaran, K. et al. Managing environmental contamination through phytoremediation by invasive plants: A review. Ecol. Eng. 138, 28-37 (2019).

27. Lee, J. H. An overview of phytoremediation as a potentially promising technology for environmental pollution control. Biotechnol. Bioprocess Eng. 18, 431-439 (2013).

28. Edao, H. G. Heavy metals pollution of soil; toxicity and phytoremediation techniques. Int. J. Adv. Res. Publ. 1, 29-41 (2017).

29. Fasani, E., Manara, A., Martini, F., Furini, A. \& Dalcorso, G. The potential of genetic engineering of plants for the remediation of soils contaminated with heavy metals. Plant Cell Environ. 41, 1210-1232 (2017).

30. Tangahu, B. V. et al. A review on heavy metals ( $\mathrm{As}, \mathrm{Pb}$, and $\mathrm{Hg}$ ) uptake by plants through phytoremediation. Int. J. ofChemical Eng. 2011, 1-31 (2011).

31. Hossain, M. A., Piyatida, P., Teixeira, J. A. \& Fujita, M. Molecular mechanism of heavy metal toxicity and tolerance in plants: Central role of glutathione in detoxification of reactive oxygen species and methylglyoxal and in heavy metal chelation. J. Bot. 2012, 1-37 (2012).

32. Anjum, N. A. et al. Jacks of metal/metalloid chelation trade in plants-an overview. Front. Plant Sci. 6, 1-17 (2015). 
33. Chen, L., Wang, D., Long, C. \& Cui, Z. Effect of biodegradable chelators on induced phytoextraction of uranium- and cadmiumcontaminated soil by Zebrina pendula Schnizl. Sci. Rep. 9, 19817 (2019).

34. Dipu, S., Kumar, A. A. \& Thanga, S. G. Effect of chelating agents in phytoremediation of heavy metals. Remediat. J. 22, 133-146 (2012).

35. Xia, S. et al. A critical review on bioremediation technologies for $\mathrm{Cr}$ (VI)-contaminated soils and wastewater. Crit. Rev. Environ. Sci. Technol. https://doi.org/10.1080/10643389.2018.1564526 (2019).

36. Raman, J. K. \& Gnansounou, E. A review on bioremediation potential of vetiver grass. In Waste Bioremediation (eds Varjani, S. J. \& Al, E.) 127-140 (Springer Nature Singapore Pte Ltd, 2018).

37. Pk, I., As, A. K. \& Pm, N. Agrotechniques for quality planting material production in vetiver (Chrysopogon zizanioides (L.) Nash.). J. Med. Plants Stud. 7, 211-213 (2019).

38. Panja, S., Sarkar, D. \& Datta, R. Removal of antibiotics and nutrients by Vetiver grass (Chrysopogon zizanioides) from secondary wastewater effluent. Int. J. Phytoremediat. 22, 764-773 (2020).

39. Darajeh, N., Truong, P., Rezania, S., Alizadeh, H. \& Leung, D. W. M. Effectiveness of vetiver grass versus other plants for phytoremediation of contaminated water. J. Environ. Treat. Tech. 7, 485-500 (2019).

40. Kiiskila, J. D., Li, K., Sarkar, D. \& Datta, R. Metabolic response of vetiver grass (Chrysopogon zizanioides) to acid mine drainage. Chemosphere 240, 124-961 (2020).

41. Thakur, S. et al. Plant-driven removal of heavy metals from soil: Uptake, translocation, tolerance mechanism, challenges, and future perspectives. Environ. Monit. Assess. 188, 206 (2016).

42. Mukta, R. H., Khatun, M. R. \& Huda, A. K. M. N. Calcium induces phytochelatin accumulation to cope with chromium toxicity in rice (Oryza sativa L.). J. Plant Interact. 14, 295-302 (2019).

43. Williams, L. E. \& Mills, R. F. P 1B-ATPases: An ancient family of transition metal pumps with diverse functions in plants. Trends Plant Sci. 10, 491-502 (2005).

44. Hall, J. L. Cellular mechanisms for heavy metal detoxification and tolerance. J. Exp. Bot. 53, 1-11 (2002).

45. Roongtanakiat, N. Vetiver Phytoremediation for Heavy Metal Decontamination. PRVN Tech. Bull. (ORDPB, 2009).

46. Page, V. \& Feller, U. Heavy metals in crop plants: Transport and redistribution processes on the whole plant level. Agronomy 5, $447-463$ (2015).

47. Centofanti, T. et al. Xylem exudate composition and root-to-shoot nickel translocation in Alyssum species Xylem exudate composition and root-to-shoot nickel translocation in Alyssum species. Plant Soil 373, 59-75 (2013).

48. Singh, H. P., Mahajan, P., Kaur, S., Batish, D. R. \& Koh, R. K. Chromium toxicity and tolerance in plants. Environ. Chem. Lett. 11, 229-254 (2013).

49. Chen, C., Huang, D. \& Liu, J. Functions and toxicity of nickel in plants: Recent advances and future prospects. Clean 37, 304-313 (2009).

50. Bluskov, S. Distribution of Chromium and Its Effect on Morphology and Anatomy of Brassica Juncea (Indian Mustard) and Soil Microorganisms (The University of Northern British Columbia, 2004).

51. di Toppi, L. S., Fossati, F., Musetti, R., Mikerezi, I. \& Favali, M. A. Effects of hexavalent chromium on maize, tomato, and cauliflower plants. J. Plant Nutr. 25, 701-717 (2002).

52. Fargasova, A. Plants as models for chromium and nickel risk assessment. Ecotoxicology 21, 1476-1483 (2012).

53. Shahid, M. et al. Foliar heavy metal uptake, toxicity and detoxification in plants: A comparison of foliar and root metal uptake. J. Hazard. Mater. 326, 36-58 (2016).

54. Mufarrege, M. M. et al. Organic matter effects on the Cr (VI) removal efficiency and tolerance of Typha domingensis. Water Air Soil Pollut. 229, 1-12 (2018).

55. V, D. V. \& Sushama, P. K. Heavy Metal Contamination of Dumpyard Soils and its Phytoremediation with Vetiver Grass ( Chrysopogon zizaniodes ). Nat. environment. Pollut. Technol. 16, 257-260 (2017).

56. Bader, N., Alsharif, E., Nassib, M., Alshelmani, N. \& Alalem, A. Phytoremediation potential of Suaeda vera for some heavy metals in roadside soil in Benghazi, Libya. Asian J. Green Chem. 3, 82-90 (2019).

57. Masarovicova, E., Kralova, K. \& Kummerova, M. Principles of classification of medicinal plants as hyperaccumulators or excluders. Acta Physiol. Plant. 32, 823-829 (2010).

58. Anderson, L. L. Assessment of Thelypteris palustris, Asparagus sprengeri, and Lolium perenne for Their Potential Use in the Phytoremediation of Arsenic- Contaminated Soils (Louisiana State University, 2007).

59. Sinha, V., Pakshirajan, K. \& Chaturvedi, R. Chromium tolerance, bioaccumulation and localization in plants: An overview. J. Environ. Manage. 206, 715-730 (2018).

60. Greger, M. Metal availability, uptake, transport and accumulation in plants. In Heavy Metal Stress in Plants Heavy (ed. Prasad, M. N.) (Springer-Verlag, Berlin Heidelberg, 2004).

61. Sajad, M. A. et al. Evaluation of chromium phytoremediation potential of some plant species of Dir Lower, Khyber, Pakhtunkhwa, Pakistan. Acta Ecol. Sin. https://doi.org/10.1016/j.chnaes.2019.12.002 (2019).

62. Yap, C. K., Ismail, A., Tan, S. G. \& Omar, H. Accumulation, depuration and distribution of cadmium and zinc in the green-lipped mussel Perna viridis (Linnaeus) under laboratory conditions. Hydrobiologia 498, 151-160 (2003).

\section{Acknowledgements}

The authors acknowledge the Research Unit for Clean Technology (LPTB)-Indonesian Institute of Sciences (LIPI), Bandung, Indonesia for the financial support.

\section{Author contributions}

All authors conceived and designed the study. Z.B.P. carried out the experiment. Z.B.P., T.S., A.P.N., and E.S.B.B. performed the statistical analysis. All authors contributed to the writing of the paper and reviewed the manuscript. All authors contributed equally.

\section{Competing interests}

The authors declare no competing interests.

\section{Additional information}

Correspondence and requests for materials should be addressed to E.S.B.B.

Reprints and permissions information is available at www.nature.com/reprints.

Publisher's note Springer Nature remains neutral with regard to jurisdictional claims in published maps and institutional affiliations. 
(c) (i) Open Access This article is licensed under a Creative Commons Attribution 4.0 International cc) License, which permits use, sharing, adaptation, distribution and reproduction in any medium or format, as long as you give appropriate credit to the original author(s) and the source, provide a link to the Creative Commons licence, and indicate if changes were made. The images or other third party material in this article are included in the article's Creative Commons licence, unless indicated otherwise in a credit line to the material. If material is not included in the article's Creative Commons licence and your intended use is not permitted by statutory regulation or exceeds the permitted use, you will need to obtain permission directly from the copyright holder. To view a copy of this licence, visit http://creativecommons.org/licenses/by/4.0/.

(C) The Author(s) 2021 